\title{
SINERGITAS AKTOR KEPENTINGAN DALAM PENYELENGGARAAN PEMERINTAHAN DESA \\ (Studi pada Desa Urek-Urek Kecamatan Gondanglegi Kabupaten Malang)
}

\author{
Akbar Pandu Dwinugraha \\ Dosen Program Studi Administrasi Publik, FISIP Universitas Merdeka Malang \\ Email: ap.dwinugroho@gmail.com
}

\begin{abstract}
The village government in its implementation can not be alone carried out by the actors of village government but also needs to be assisted by other stake actors even though the village head becomes the main actor in building synergies with other stake actors with good results on the contrary. Descriptive research with qualitative approach is used in this study with the aim to analyze the synergy of interest actors in the administration of village government in UrekUrek Village, Gondanglegi Sub-district, Malang Regency. Based on the analysis that has been conducted this research has resulted in the conclusion that among other things the communication that has been built, by the village government and other actors of interest has run well although the optimization especially communication by the village government together with women and poor groups which seems rarely done. Coordination that is built among actors of interest has also been running well although it is still deemed necessary made improvements including related aspects of direct relationships, preliminary planning and clear formulation of authority and responsibility.
\end{abstract}

Key words: Village, Synergies, communication, coordination.

\section{PENDAHULUAN}

Sinergitas antar aktor kepentingan merupakan suatu hal yang sangat penting dalam pencapaian suatu tujuan organisasi. Tak ubahnya keilmuan administrasi publik yang menganggap administrasi sebagai kerjasama antara dua orang atau lebih untuk mencapai tujuan, sinergitas juga merupakan kombinasi atau paduan unsur/bagian yang dapat menghasilkan keluaran lebih baik dan lebih besar ketika dibangun secara baik bersama stakeholders yang ada didalamnya (Najianti dalam Rahmawati et al. 2011). Berdasarkan hal tersebut sinergitas memposisikan dirinya sebagai katalisator dari keilmuan administrasi yang bertujuan untuk mencapai tujuan organisasi dengan hasil yang lebih maksimal.

Sinergitas dapat terbangun melalui komunikasi dan koordinasi. Dimana komunikasi dibedakan menjadi dua bagian Volume 2, Nomor 1, April 2017 yang mana disatu sisi merupakan kegiatan seseorang memindahkan stimulus guna mendapatkan tanggapan dan disisi lain sebagai kegiatan menanggapi stimulus tersebut (sofyandi dan Garniwa, 2007). Disamping komunikasi, sinergitas juga membutuhkan koordinasi yang merupakan integrasi dari kegiatan-kegiatan individual dan unit-unit ke dalam satu usaha bersama yaitu bekerja kearah tujuan bersama (Silalahi, 2011).

Dalam keilmuan administrasi publik, konsep sinergitas merupakan suatu cara yang harus dilakukan pemerintah dalam menjalankan pemerintahan demi mencapai kesejahteraan masyarakat. Pemerintah dalam hal ini meliputi pemerintah tingkat pusat sampai dengan pemerintah tingkat bawah atau sering kita kenal dengan istilah pemerintah desa. Pemerintah desa merupakan aktor kepentingan yang berwenang dalam 
menyelenggarakan Pemerintahan Desa. Berdasarkan Undang-Undang No. 6 Tahun 2014 tentang Desa, Pemerintahan desa merupakan penyelenggaraan urusan pemerintahan dan kepentingan masyarakat setempat dalam sistem pemerintahan negara kesatuan republik indonesia.

Dalam perjalanan ketatanegaraan Republik Indonesia, desa telah berkembang dalam berbagai bentuk sehingga perlu untuk dilindungi dan diberdayakan agar semakin kuat, maju, mandiri dan demokratis sehingga dapat menciptakan landasan yang kuat dalam melaksanakan pemerintahan dan pembangunan menuju masyarakat yang adil, makmur dan sejahtera. Sayangnya dalam rangka mencapai hal tersebut Pemerintahan desa dalam penyelenggaraannya tidak bisa sendiri dilakukan oleh pemerintah desa, tetapi juga perlu dibantu oleh aktor kepentingan yang lainnya, meskipun kepala desalah yang menjadi aktor utama yang menentukan sinergi bersama aktor kepentingan yang lainnya berjalan baikkah atau tidak. Aktor-aktor tersebut terdiri dari kelompok-kelompok masyarakat yang meliputi kelompok petani, kelompok nelayan, kelompok masyarakat miskin, kelompok perempuan. Tokoh masyarakat, tokoh agama, tokoh adat juga menjadi aktor kepentingan yang mempengaruhi perkembangan desa kearah yang lebih baik. Selain itu, lembaga-lembaga desa yang meliputi Lembaga Pemberdayaan Masyarakat (LPM) dan Badan Permusyawaratan Desa (BPD). Seluruh aktor kepentingan tersebut menjadi bagian yang utuh dan bersinergi untuk menyelenggarakan
Pemerintahan Desa dengan tujuan untuk mensejahterakan masyarakat desa.

Salah satu desa yang berada dalam wilayah administratif Kabupaten Malang adalah Desa Urek-Urek. Desa ini berada di wilayah Kecamatan Gondanglegi. Desa UrekUrek merupakan desa yang tergolong dari tingkat perkembangan desanya masih dalam tataran desa berkembang. Perkembangan tersebut didukung dengan adanya pemilihan kepala desa secara langsung yang baru-baru ini terselenggara di desa tersebut. Desa UrekUrek menjadi satu-satunya desa di wilayah Kecamatan Gondanglegi yang melaksanakan pemilihan kepala desa langsung di Kabupaten Malang. Maka dari itu hal ini menjadi sesuatu yang sangat menarik ketika penelitian ini nantinya akan menjadi asupan gizi yang bermanfaat bagi pemerintah desa yang baru dalam rangka penyelenggaraan pemerintahan desa kearah yang lebih baik dan bersinergi antar seluruh stakeholders yang ada didalamnya.

\section{TINJAUAN PUSTAKA \\ Administrasi Publik}

Administrasi Publik adalah studi mengenai bagaimana bermacam-macam badan pemerintah diorganisasi, diperlengkapi dengan tenaga tenaganya, dibiayai, digerakkan, dan dipimpin (Syafii,2003). Selain itu, Pasolong(2007) mendefinisikan administrasi publik meliputi:

a. Suatu kerjasama kelompok dalam lingkungan pemerintahan

b. Meliputi tiga cabang pemerintahan eksekutif, legislatif, dan serta hubungan diantara mereka. 
c. Mempunyai peranan penting dalam perumusan kebijakan pemerintah, dan karenanya merupakan sebagian dari proses politik.

d. Sangat erat berkaitan dengan berbagai macam kelompok swasta dan perorangan dalam menyajikan pelayanan kepada masyarakat.

e. Dalam beberapa hal berbeda pada penempatan pengertian dengan administarasi perorangan.

\section{Sinergitas Aktor Kepentingan}

Sinergitas aktor kepentingan bisa diartikan sebagai hubungan sinergi yang dibangun oleh para aktor kepentingan. Najiyati dalam Rahmawati et al. (2014), mengartikan sinergi sebagai kombinasi atau paduan unsur atau bagian yang dapat menghasilkan keluaran lebih baik dan lebih besar. Jadi sinergi dapat dipahami sebagai operasi gabungan atau perpaduan unsur untuk menghasilkan output yang lebih baik. Sinergitas dapat terbangun melalui dua cara yaitu:

\section{a. Komunikasi}

Sofyandi dan Garniwa dalam bukunya Perilaku Organisasional (2007) menjelaskan pengertian komunikasi dapat dibedakan atas dua bagian yaitu (1)komunikasi yang berorientasi pada sumber yang menyatakan bahwa komunikasi adalah kegiatan dengan mana seseorang secara sungguh-sungguh memindahkan stimulan guna mendapatkan tanggapan. Sedangkan (2)komunikasi yang berorientasi pada penerima memandang bahwa, komunikasi sebagai semua kegiatan di mana seseorang (penerima) menanggapi stimulus atau rangsangan.

b. Koordinasi

Disamping adanya komunikasi dalam menciptakan sinergitas juga memerlukan koordinasi. Silalahi (2011) dalam bukunya yang berjudul Asas-asas Manajemen menjelaskan bahwa koordinasi adalah integrasi dari kegiatan-kegiatan individual dan unit-unit ke dalam satu usaha bersama yaitu bekerja kearah tujuan bersama". Sedangkan Moekijat dalam Rahmawati et al. (2014) menyebutkan ada 9 (sembilan) syarat untuk mewujudkan koordinasi yang efektif, yaitu: 1) Hubungan langsung: Bahwa koordinasi dapat lebih mudah dicapai melalui hubungan pribadi langsung; 2) Kesempatan awal: Koordinasi dapat dicapai lebih mudah dalam tingkat-tingkat awal perencanaan dan pembuatan kebijaksanaan; 3) Kontinuitas Koordinasi: merupakan suatu proses yang kontinu dan harus berlangsung pada semua waktu mulai dari tahap perencanaan; 4) Dinamisme: Koordinasi harus secara terusmenerus diubah mengingat perubahan lingkungan baik intern maupun ekstern; 5) Tujuan yang jelas: Tujuan yang jelas itu penting untuk memperoleh koordinasi yang efektif; 6) Organisasi yang sederhana: Struktur organisasi yang sederhana memudahkan koordinasi yang efektif; 7) Perumusan wewenang dan tanggung jawab yang jelas: Wewenang yang jelas tidak hanya mengurangi pertentangan di antara pegawai-pegawai yang berlainan, tetapi juga membantu mereka dalam pekerjaan dengan kesatuan tujuan; 8) Komunikasi yang efektif: Komunikasi yang efektif merupakan salah satu persyaratan 
untuk koordinasi yang baik; dan 9) Kepemimpinan supervisi yang efektif: Kepemimpinan yang efektif menjamin koordinasi kegiatan orang-orang, baik pada tingkat perencanaan maupun pada tingkat.

\section{Pemerintahan Desa}

Pemerintahan desa secara garis besar merupakan pemerintahan yang berlangsung di desa dan dilakukan oleh pemerintah desa yang dipimpin oleh Kepala Desa. Pemerintah desa dalam hal ini adalah kepala desa dibantu oleh perangkat desa. Berdasarkan Undang-Undang No. 6 Tahun 2014 tentang Desa, Pemerintahan desa merupakan penyelenggaraan urusan pemerintahan dan kepentingan masyarakat setempat dalam sistem pemerintahan negara kesatuan republik indonesia, sedangkan pengertian desa adalah kesatuan masyarakat hukum yang memiliki batas wilayah yang berwenang untuk mengatur dan mengurus urusan pemerintahan, kepentingan masyarakat setempat berdasarkan prakarsa masyarakat, hak asal usul dan/atau hak tradisional yang diakui dan dihormati dalam sistem pemerintahan Negara Kesatuan republik Indonesia. Dalam perjalanan ketatanegaraan Republik Indonesia, desa telah berkembang dalam berbagai bentuk sehingga perlu untuk dilindungi dan diberdayakan agar semakin kuat, maju, mandiri dan demokratis sehingga dapat menciptakan landasan yang kuat dalam melaksanakan pemerintahan dan pembangunan menuju masyarakat yang adil, makmur dan sejahtera.

\section{METODE PENELITIAN}

Penelitian ini menggunakan jenis penelitian deskriptif dengan pendekatan kualitatif, dimana menurut Kirk dan Miller dalam Moleong (2009), penelitian kualitatif itu adalah tradisi tertentu dalam ilmu pengetahuan sosial yang secara fundamental bergantung pada pengamatan manusia dalam kawasannya sendiri dan berhubungan dengan orang-orang tersebut dalam bahasanya dan peristilahannya. Sedangkan Bogdan dan Taylor dalam Moleong (2009) memberikan definisi metodologi kualitatif adalah sebagai prosedur penelitian yang menghasilkan data deskriptif berupa kata-kata tertulis atau lisan dari orang-orang atau perilaku yang dapat diamati. Karakteristik lain dari penelitian kualitatif adalah penekanannya pada pandangan fenomena secara menyeluruh (holistik view) (Moleong, 2008).

\section{PEMBAHASAN}

Sinergitas aktor kepentingan dalam penyelenggaraan pemerintahan desa yang baik di Desa Urek-Urek Kecamatan Gondanglegi Kabupaten Malang dipengaruhi oleh sinergitas antar aktor kepentingan. Berikut ini adalah deskripsi dan pembahasan terkait sinergitas antar aktor kepentingan dalam penyelenggaraan pemerintahan desa yang akan ditelaah berdasarkan beberapa indikator sinergi yang meliputi komunikasi dan koordinasi.

\section{a. Komunikasi}

Komunikasi yang terjalin dalam penyelenggaraan pemerintahan di Desa UrekUrek dijalin secara formal dan informal. Formal dalam hal ini berkaitan dengan komunikasi yang dibangun dalam lingkup 
internal antara kepala desa, perangkat desa, Badan Permusyawaratan Desa dan Lembaga Keswadayaan Masyarakat Desa. Sedangkan komunikasi informal berhubungan dengan komunikasi yang dibangun oleh Kepala Desa diluar forum resmi pemerintahan desa seperti hubungan baik yang dijalin kepala desa dengan lawan politiknya terdahulu. Hal ini dilakukan demi penyelenggaraan pemerintahan desa yang baik dan partisipatif. Selain itu komunikasi yang dibangun oleh pemerintah desa bersama tokoh adat, tokoh agama, tokoh masyarakat telah berlangsung baik tetapi sayangnya komunikasi yang seharusnya juga dibangun bersama kelompok perempuan dan kelompok masyarakat miskin terkesan jarang dilakukan.

\section{b. Koordinasi}

Berdasarkan 9 (sembilan) sub indikator yang telah dipaparkan pada bab sebelumnya, peneliti menentukan 6 (enam) sub indikator yang digunakan dalam menganalisis sinergi yang terbangun antara pemerintah desa dan aktor kepentingan yang ada dalam menyelenggarakan pemerintahan desa yang meliputi.

1) Hubungan langsung

Berdasarkan analisis dilapangan yang telah dilakukan aspek hubungan langsung yang tebangun antara pemerintah desa dengan stakeholders di Desa Urek-Urek telah berjalan baik meskipun intensitas informasi yang diberikan dalam tataran yang tidak sering. Hal tersebut terbukti dengan kurang tersalurkannya informasi dari pemerintah desa yang secara langsung disampaikan kepada masyarakat desa dan masih kurangnya koordinasi yang dilakukan oleh pemerintah desa dilakukan secara langsung dan partisipatif terutama terhadap kelompok perempuan.

\section{2) Perencanaan Awal}

Perencanaan awal berkaitan dengan perencanaan pemerintah desa dalam penyelenggaraan pemerintahan desa yang perlu dikoordinasikan dengan perangkat desa yang juga sebagai aktor kepentingan di desa. Hal tersebut meliputi bentuk konsultasi yang dibangun pemerintah desa dengan stakholders di desa dalam pengajuan rancangan peraturan desa, struktur organisasi dan tata kerja pemerintah desa, serta keikutsertaan masyarakat dalam perencanaan pembangunan desa. Berdasarkan analisis yang telah dilakukan, masyarakat jarang diajak dalam forum penyusunan rancangan peraturan desa, organisasi desa urek-urek jarang mengalami perubahan meski tejadi pergantian kepala desa dan pemerintah desa jarang mengkolsultasikan peraturan desa kepada masyarakat.

3) Keberlanjutan

Keberlanjutan berkaitan dengan tanggungjawab yang diemban pemerintah desa yang secara berkesinambungan dibangun bersama masyarakat dan aktor kepentingan di Desa. Beberapa hal yang diteliti dalam indikator ini adalah sejauhmana pemerintah desa bersama masyarakat dan aktor kepentingan terkait dalam memeliharan ketentraman dan ketertiban masyarakat desa, melestarikan nilai sosial budaya dan mengembangkan sumber pendapatan desa. Berdasarkan analisis yang telah dilakukan pemerintah bersama masyarakat dan aktor kepentingan terkait, sinergi yang dihasilkan 
bisa dikatakan telah terbangun secara baik, meski terdapat keluhan masyarakat terkait sumber pendapatan desa yang dirasa kurang dimanfaatkan secara optimal dan berdampak manfaat kepada masyarakat Desa Urek-Urek.

4) Kedinamisan

Kedinamisan terkait dengan penyelenggaraan pemerintahan desa oleh pemerintah desa dalam memberikan pelayanan kepada masyarakat desa. Hal yang diteliti adalah sinergi yang dibangun pemerintah desa beserta masyarakat dan stakeholders di desa dalam melayani administrasi pemerintahan desa yang baik, serta melaksanakan prinsip akuntabel, transparan, profesional, efektif, efisien dan bersih dari KKN, dan sejauh mana pemerintah desa bersinergi dalam meningkatkan pelayanan administrasi tersebut bersama dengan masyarakat dan aktor kepentingan yang lainnya. Hasil analisis yang telah dilakukan di lapangan menyebutkan sinergi yang dibangun pemerintah desa telah berjalan dengan baik. Hal ini terdukung oleh data persepsi masyarakat yang menyatakan bahwa pelayanan administrasi di Desa Urek-Urek dirasa telah memuaskan. Hal ini didukung juga dengan keterbukaan oleh pemerintah desa dalam menampung aspirasi dan keluhan masyarakat desa terkait pelayanan administrasi desa sebagai bentuk sinergi yang dibangun pemerintah desa dalam memperbaiki kualitas pelayanan.

5) Tujuan yang jelas

Tujuan yang jelas mendeskripsikan sejauhmana pemerintah desa dan aktor kepentingan yang ada memegang dan mengamalkan pancasila dan UUD 1945 dan memelihara keutuhan NKRI, sejauhmana pemerintah desa dan aktor kepentingan yang adameningkatkan kesejahteraan masyarakat serta sejauhmana pemerintah desa dan aktor kepentingan yang adamenaati dan menegakkan peraturan perundang- undangan. Berdasarkan analisis yang telah dilakukan dilapangan, sinergi yang terbangun antara pemerintah desa, masyarakat dan stakeholders di Desa Urek-Urek telah berlangsung dengan baik dalam hal menjaga nilai-nilai kenegaraan dan keutuhan NKRI serta sinergi dalam hal menegakkan peraturan perundang-undangan. Hal ini didukung dengan informasi dari masyarakat bahwa ketika konflik terjadi di Desa Urek-Urek selalu diselesaikan sesegera mungkin untuk menjamin keamanan dan ketentraman penduduk desa.

2) Perumusan wewenang dan tanggungjawab yang jelas

Perumusan

wewenang

dan tanggungjawab yang jelas diselenggarakan oleh pemerintah Desa Urek-Urek Kecamatan Gondanglegi Kabupaten Malang ditelaah berdasarkan beberapa hal antara lain kondisi sinergi antara pemerintah desa dan aktor kepentingan yang adadalam melaksanakan kehidupan demokrasi serta sejauhmana pemerintah desa dan aktor kepentingan yang adamelaksanakan kehidupan berkeadilan gender.

Berdasarkan analisis yang telah dilakukan Kepala desa Urek-Urek bisa dikatakan jarang dalam memberikan mandat dan tugas serta kewajiban kepada perangkat desa. Kepemimpinan yang dijalankan Kepala Desa secara internal bersifat bebas. Berdasarkan hal tersebut sinergitas yang 
terjalin oleh kepala desa, perangkat desa dan masyarakat didominasi oleh perangkat desa dalam penyusunannya. Sinergi yang dibangun oleh pemerintah desa dan masyarakat dalam melaksanakan kehidupan berkeadilan genderpun juga terlihat kurang. Beberapa informan terutama kaum perempuan menyatakan pemerintah desa kurang memberikan akses terhadap mereka dalam menyalurkan partisipasinya. Berdasarkan analisis terhadap sub indikator perumusan wewenang dan tanggungjawab, sinergi yang dibangun pemerintah desa terkesan kurang berjalan dengan baik.

\section{KESIMPULAN}

Berdasarkan hasil penelitian, maka dapat disimpulkan bahwa sinergitas aktor kepentingan di Desa Urek-Urek Kecamatan Gondanglegi Kabupaten Malang dalam rangka penyelenggaraan pemerintahan desa sudah berjalan baik meski perlu terus dilakukan optimalisasi. Bahwa komunikasi yang telah dibangun oleh pemerintah desa dan aktor kepentingan lainnya telah berjalan dengan baik meski ada beberapa hal yang perlu dilakukan optimalisasi terutama komunikasi oleh pemerintah desa bersama kelompok perempuan dan kelompok masyarakat miskin terkesan jarang dilakukan.

Koordinasi yang dibangun antar aktor kepentingan juga telah berjalan dengan baik meski ada beberapa hal yang perlu dilakukan peningkatan diantaranya terkait sub indikator hubungan langsung, perencanaan awal dan perumusan wewenang dan tanggung jawab yang jelas.
Diharapkan sinergi antar aktor kepentingan yang ada terutama Pemerintah Desa di Desa Urek-Urek dapat terbangun semakin baik dengan meningkatkan aspek partisipatif dalam melakukan koordinasi dengan aktor kepentingan lainnya, mengikutsertakan masyarakat terutama kelompok perempuan di desa serta Kepala Desa mampu menjadi pemimpin desa yang secara demokratis dapat membimbing perangkat desa serta berkoordinasi dengan seluruh lapisan masyarakat desa tanpa terkecuali.

\section{DAFTAR PUSTAKA}

Lexy J. Moleong. (2008). Metodologi Penelitian Kualitatif. Bandung :Remaja Rosdakarya.

Moleong, J Lexy, Prof. Dr. 2009, Metode Penelitian Kualitatif. Bandung : PT. Remaja Rosdakaya

Pasolong. Harbani. (2007). Teori Administrasi Publik. Bandung: Alfabeta.

Rahmawati, Triana et al.(2014) Sinergitas Stakeholders Dalam Inovasi Daerah. Jurnal Administrasi Publik (JAP) Vol. 2, No. 4, Hal. 641-647

Silalahi, Ulbert. (2011). Asas-Asas Manajemen. Bandung: Refika Aditama.

Sofyandi, Herman dan Iwa Garniwa. (2007). Perilaku Organisasional, Yogyakarta: Graha Ilmu

Syafii, Inu Kencana. 2003.Sistem Administrasi Negara Republik Indonesia. Bandung: PT Bumi Aksara.

Undang-Undang Negara Republik Indonesia Nomor 6 Tahun 2014 tentang Desa 